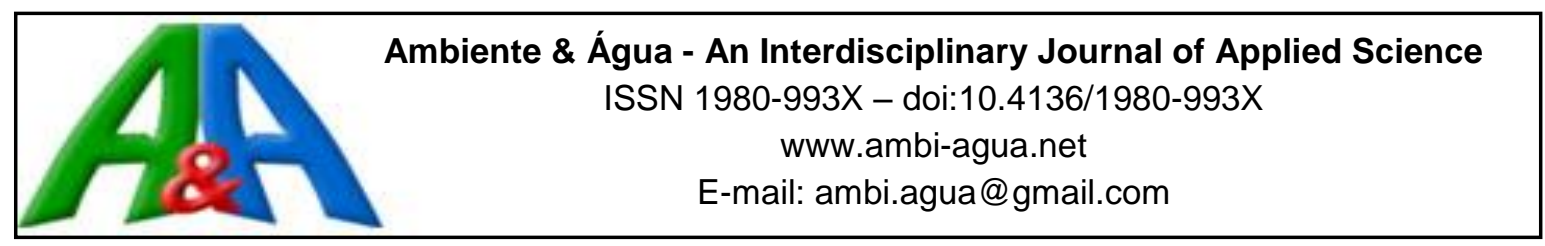

\title{
Estimation of plant productivity and nutrient extraction capacity along the length of horizontal subsurface flow constructed wetland treating swine wastewater
}

\author{
ARTICLES doi:10.4136/ambi-agua.1979
}

Received: 03 Aug. 2016; Accepted: 26 Mar. 2018

\author{
Renata Gaudereto Andries $^{1 *}$; Antonio Teixeira de Matos ${ }^{1}$; Wallisson da Silva Freitas ${ }^{2}$ \\ ${ }^{1}$ Universidade Federal de Minas Gerais (UFMG), Belo Horizonte, MG, Brasil \\ Departamento de Engenharia Ambiental e Sanitária. E-mail: renatagauderetoandries@gmail.com, \\ atmatos@desa.ufmg.br \\ ${ }^{2}$ Instituto Federal de Educação, Ciência e Tecnologia do Espirito Santo (IFES), Ibatiba, ES, Brasil \\ E-mail: wallissonfreitas@yahoo.com.br \\ *Corresponding author
}

\begin{abstract}
The plant productivity and extraction capacity of nutrients present in swine wastewater (SWW) were quantified over 60 days in three horizontal subsurface flow constructed wetlands (HSSF-CW) grown with three different plant species (Typha latifolia, Alternanthera philoxeroides and Cynodon dactylon). The results show the decay of the dry matter yield (DMY) and the nutrient extraction capacity (NEC) by the plants throughout the system, which gave rise to the equations that relate these parameters to the hydraulic retention time (HRT) for each species. When possible, general equations that are independent of the plant species were also evaluated. The best model fit for the dry matter yield and N-total, $\mathrm{N}$-ammoniacal, N-nitrate and $\mathrm{P}$ extraction by plants as a function of HRT was the decreasing potential and for $\mathrm{K}$ extraction was the linear regression. The coefficients of determination of equations for the species Alternanthera philoxeroides and Cynodon dactylon were, for the most part, higher than 0.8 . On the other hand, the general equations presented coefficient of determination greater than $90 \%$ in all cases.
\end{abstract}

Keywords: modeling, pig farming, wastewater.

\section{Estimativa da produtividade e extração de nutrientes pelas plantas ao longo do comprimento de sistemas wetlands construídos tratando águas residuárias da suinocultura}

\section{RESUMO}

A produtividade e a capacidade de extração de nutrientes presentes na água residuária da suinocultura (SSW), pelas plantas, foi quantificada ao longo de 60 dias em três wetlands construídos de escoamento horizontal subsuperficial (HSSF-CW), cultivados com três diferentes espécies vegetais (Typha latifolia, Alternanthera philoxeroides e Cynodon dactylon). Os resultados mostram o decaimento da produtividade de matéria seca (DMY) e da capacidade de extração de nutrientes (NEC) pelas plantas ao longo do sistema, que proporcionaram a obtenção de equações que relacionam esses parâmetros com o tempo de detenção hidráulica 
(HRT) para cada espécie. Quando possível, equações gerais que independem da espécie plantada também foram avaliadas. $\mathrm{O}$ modelo de melhor ajuste aos dados de produtividade de matéria seca e extração de $\mathrm{N}$-total, $\mathrm{N}$-amoniacal, $\mathrm{N}$-nitrato e $\mathrm{P}$ pelas plantas em função do HRT foi o potencial decrescente e para extração de $\mathrm{K}$, foi o linear decrescente. Os coeficientes de determinação das equações para as espécies Alternanthera philoxeroides e Cynodon dactylon, em sua maioria, foram superiores a 0.8. Já as equações gerais apresentaram coeficiente de determinação maior que $90 \%$, em todos os casos.

Palavras-chave: água residuária, modelagem, suinocultura.

\section{INTRODUCTION}

Pig farming is of considerable economic, social and environmental importance globally, with pork the most-consumed source of animal protein in the world (ABCS, 2016). From the environmental point of view, the wastewater discharge, treated or not, causes severe environmental impacts on water bodies. Piggery effluents contain high contents of organic matter that cause oxygen depletion, biodiversity losses and environmental degradation in aquatic ecosystems. Nutrients present in these wastewaters, mainly nitrogen, phosphorus and potassium, when in high concentrations, can trigger eutrophication, even in lotic water bodies, also causing environmental degradation

The characteristics of swine effluent, in relation to physical, chemical and biological parameters, depends on its dilution, and this depends on water uses/management in pig farms.

According to Perdomo et al. (2001) the concentration of Dry matter, $\mathrm{BOD}_{5}{ }^{20}$, Total Nitrogen, Total Phosohorus and Total Potassium varies from 5.7 to $2.9 \%, 16.1$ to $8.1 \mathrm{~kg} \mathrm{~m}^{3}, 2.7$ to $1.4 \mathrm{~kg} \mathrm{~m}^{-3}, 0.94$ to $0.47 \mathrm{~kg} \mathrm{~m}^{-3}$ and 1.5 to $0.75 \mathrm{~kg} \mathrm{~m}^{-3}$, respectively.

According to ABCS (2016), in 2015 the Brazilian reproductive stock was 1,720,255 breeding sows that produced 39,263,964 piglets that were subsequently slaughtered. The complete pig breeding cycle generates from 140 to $170 \mathrm{~L} \mathrm{sow}^{-1}$ day $^{-1}$ and for the piglet production core the volume of waste is 35 to $40 \mathrm{~L} \mathrm{pig}^{-1}$ day $^{-1}$ (Konzen, 2003). Thus, the average generation of wastewater from Brazilian swine for the year 2015 was approximately 635 million $\mathrm{m}^{3}$.

While it is recognized that such activity is essential for the world economy, bringing many social-economic benefits, the large environmental impact on water, soil and air also needs to be considered.

Horizontal subsurface flow constructed wetlands (HSSF-CW), among many other technologies for swine wastewater treatment, offer a great alternative for treatment of such heavily loaded wastewaters. According to von Sperling (2005), CW systems have very low power requirements; do not produce byproducts, noise and aerosols; are simple to operate and maintain; reach high efficiency on BOD removal; present low costs of operation and maintenance and are resistant to variations in flow and loads.

$\mathrm{CW}$ systems are a wastewater treatment technology whose design is based on natural processes occurring in aquatic ecosystems such as marshes and swamps. According to USEPA (1999), CWs are shallow artificial systems, generally less than $1 \mathrm{~m}$ deep, filled or not with a support media like stones or sand, planted with aquatic plants, where biological, chemical and physical processes take place providing wastewater treatment. Generally, these systems must have a liner layer to prevent infiltration and soil and groundwater contamination. Hydraulic parameters such as, flow, hydraulic retention time, water depth and flow direction are controlled inside the system. The most common flow types in CWs are surface flow or vertical and horizontal subsurface flow. 
According to Vymazal (2013), the macrophytes growing in constructed wetlands have several properties in relation to the treatment process that make them an essential component of the design. Among the functions of the vegetation present in the HSSF-CWs, are included: nutrient removal from the wastewater; oxygen transfer to the substrate; exudation of substrates (rhizomes and roots) for the biofilm growth of bacteria; improvement in the permeability of the substrate and in the aesthetics of the environment (Mohammadpour et al., 2014; Wetland International, 2003; Lautenschlager, 2001).

According to Faquin (2005), there are three factors that affect the extraction of nutrients by plants: 1) factors related to the plant's absorption capacity, kinetic parameters that enable the ion fluxes to the plant; 2) factors related to the characteristics of the support medium and pore water in soil matrix, which define the rate at which a given nutrient will reach the surface of the root; and 3) the morphological factors of the vegetation, which will condition the area or surface absorbed from the root system.

For nitrogen, for example, forage vegetation can remove from 0.16 to $0.67 \mathrm{t} \mathrm{ha}^{-1} \mathrm{year}^{-1}$ and forests from 0.08 to $0.17 \mathrm{t} \mathrm{ha}^{-1}$ year ${ }^{-1}$ (Matos and Matos, 2017).

Because CWs are systems of great diversity, in constructive and operational terms, the scientific community has undertaken efforts to improve the design of these systems. The availability of models and mathematical equations that describe the mechanisms and processes that take place in the HSSF-CW become fundamental so that the costs of construction and operation can be minimized and the efficiency in the wastewater treatment can be maximized.

A number of authors (Saeed and Sun, 2011; Meyer et al., 2015) have modeled the decay of various pollutants in the wastewater within the HSSF-CW; however, it is still considered important to understand how plants influence the transformation processes, quantifying the decay of the pollutants in the system.

Thus, this article aims to develop mathematical equations of biomass productivity and nutrient uptake by the aerial part of the plant species Alternanthera philoxeroides (Alligator weed) Cynodon dactylon (Tifton 85 grass) and Typha latifolia (Cattail) along the length of three HSSF-CW treating swine wastewaters.

\section{MATERIAL AND METHODS}

\subsection{Location and experimental units characterization}

This study was conducted at the experimental Area of Hydraulics, Irrigation and Drainage of the Department of Agricultural Engineering of the Federal University of Viçosa, Minas Gerais state, Brazil. The system is basically composed of five HSSF-CW units, described as follows and depicted schematically in Figure 1.

CW1: system planted only with Typha latifolia (Cattail);

CW2: system planted only with Alternanthera philoxeroides (Alligator weed);

CW3: system planted only with Cynodon dactylon (Tifton 85 grass)

The swine wastewater treatment system was composed of a storage tank, a compost filter with sugarcane bagasse followed by HSSF-CW. The storage tank had $20 \mathrm{~m}^{3}$ capacity. The sugarcane bagasse filters had a volume of $0.5 \mathrm{~m}^{3}$ and were operated alternately. Its bed was changed 9 times throughout the experiment. The flow control tanks were $1 \mathrm{~m}^{3}$ in volume each.

The HSSF-CW analyzed were $24 \mathrm{~m}$ long, $1.1 \mathrm{~m}$ wide, and $0.7 \mathrm{~m}$ high, with a bottom slope of $0.005 \mathrm{~m} \mathrm{~m}^{-1}$. Applied wastewater flow was of $800 \mathrm{~L} \mathrm{day}^{-1}$, resulting in a hydraulic retention time (HRT) of 4.8 days and a BOD loading rate of $154.8 \mathrm{~kg} \mathrm{ha}^{-1} \mathrm{day}^{-1}$. Support media used was gneiss gravel, with an effective diameter of $7.0 \mathrm{~mm}$, uniformity coefficient of 1.6 , void volume of $48.4 \%$ and saturated hydraulic conductivity of (Ksat) of 7,970.0 $\mathrm{m} \mathrm{d}^{-1}$.

\section{IPABH}

Rev. Ambient. Água vol. 13 n. 3, e1979 - Taubaté 2018 


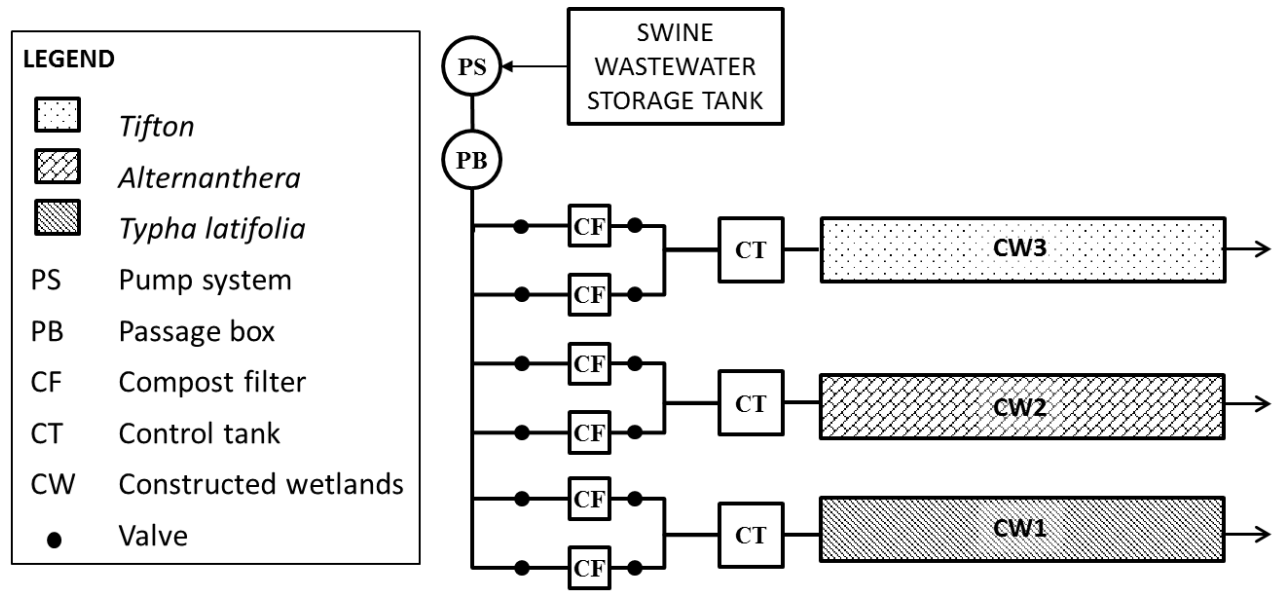

Figure 1. Units layout scheme at the experimental site of DEA/UFV.

\subsection{Sampling and analyses}

System construction occurred between 01/11/2003 and 01/02/2005. To evaluate the dry matter yield (DMY) and nutrient extraction by the aerial part of the species assessed, three cuts of plant shoots were done $(12 / 04 / 2005,24 / 07 / 2005$ and 14/11/2005) at the first, second and final third of the HSSF-CW, as schematized in Figure 2.

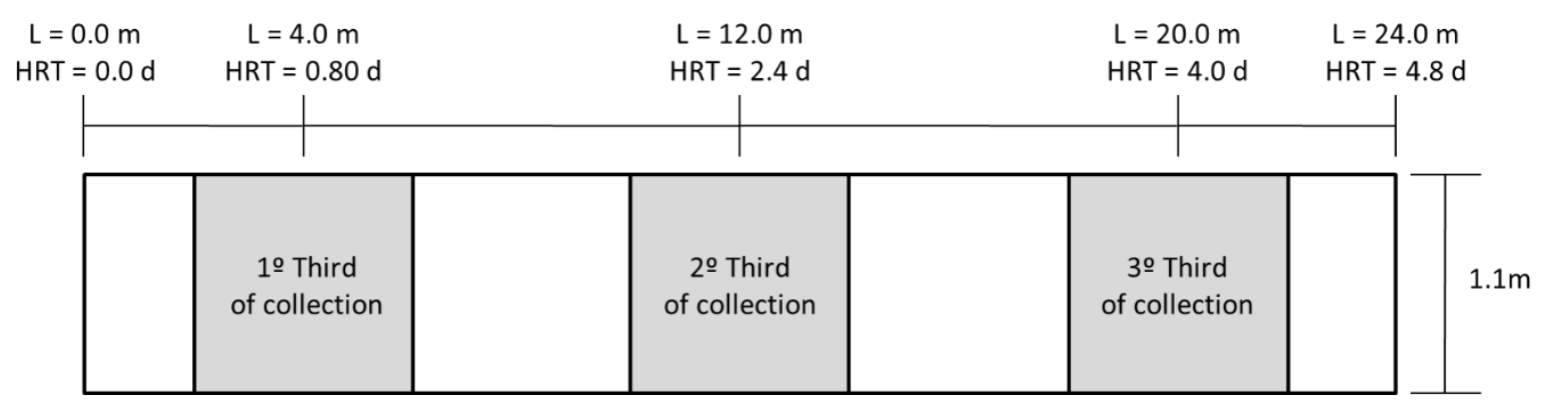

Figure 2. Schematics of harvesting thirds at the HSSF-CWs.

The harvested material was immediately weighed in order to determine the fresh matter production (FMP), dividing the biomass productivity by the sampling area $(4.0 \mathrm{~m} \times 1.1 \mathrm{~m})$. Then, all the fresh biomass was chopped and three representative samples were taken for the determination of water content, allowing the calculation of the dry matter content (DM) and sample preparation to nutrient analysis.

Samples were placed in paper bags, identified and taken to the greenhouse at $60^{\circ} \mathrm{C}$ temperature with air circulation until constant mass (pre-drying). Then, the samples were ground in a "Willey" type mill with screen 30 "mesh" and stored in paper bags for subsequent quantification of the dry matter content and nutritional analysis. Part of the sample was placed in a greenhouse at $105^{\circ} \mathrm{C}$ temperature until it reached constant mass, in order to quantify the residual water content, obtaining the total dry weight of each sample.

Dry matter yield of the aerial part (DMY) was obtained using Equation 1, while the nutrient extraction capacity (NEC) was obtained by the product of nutrient concentration (NC) in plant tissue and dry matter yield (Equation 2) in the periods between their harvests.

$D M Y=\frac{F M P \times D M}{100}$

$N E C=\mathrm{NC} \times D M P \times 10$ 
On what:

DMY: Dry matter yield in $\mathrm{tha}^{-1}$ (ton hectare ${ }^{-1}$ )

FMP: fresh matter yield in $\mathrm{t} \mathrm{ha}^{-1}$ (ton hectare ${ }^{-1}$ )

DM: dry matter content in dag kg${ }^{-1}$ (decagram kilogram ${ }^{-1}$ )

NEC: nutrient extraction capacity in $\mathrm{kg} \mathrm{ha}^{-1}$ (kilogram hectare ${ }^{-1}$ )

$\mathrm{NC}$ : nutrient concentration in dag kg-1 (decagram kilogram ${ }^{-1}$ )

\subsection{Database analysis}

The HSSF-CWs plants 1, 2 and 3, calculated from the data obtained in the three cuts done in their aerial part, were analyzed in a $3 \times 3 \times 3$ factorial $(3$ HSSF-CWs, 3 positions within each HSSF- CWs and 3 replicates at each position), with split plots, distributed in a randomized complete block design with 2 factors (factor HSSF-CW and factor positions within each HSSF$\mathrm{CW})$. When there was a significant effect on the HSSF-CW x Position interaction, the effect of one factor was compared at each level of the other, and when there was no significant effect on this interaction, the factors were assessed separately. The averages, in the case of significant effects, were compared using the Tukey test, at 5\% significance.

Dry matter yield of the aerial part (DMY) and nutrient extraction capacity (NEC) were analyzed in relation to HRT within the HSSF-CW (total of 4.8 days). As HSSF-CW had $24 \mathrm{~m}$, the HRT of 0.8 days equals the length of $4 \mathrm{~m}$, the HRT of 2.4 days the length of $12 \mathrm{~m}$ and the HRT of 4.0 days the length of $20 \mathrm{~m}$, as shown in Figure 2.

The analyzes were performed in relation to the HRT instead of the distance traveled by the effluent inside the HSSF-CW in order to standardize the results, so that they could be used in different CWs with different lengths and hydraulic loadings.

\subsection{Mathematical equations adjusted}

Mathematical equations adjusted to allow an estimation of DMY and NEC (Total-N, Ammonium-N, Nitrate-N, P and K) by plant aerial parts were firstly proposed to each species (T. latifolia-CW1; A. philoxeroides - CW2; C. dactylon-CW3).

Once the individual equations for each plant species obtained, the intensity of the relationship between two variables was quantified making use of the Pearson correlation coefficient (PCC). Thus, when the correlation obtained for the three plant species showed good correlation $(\mathrm{CCP}>0.7)$ a single equation was proposed, capable of representing the three species evaluated.

The individual equations were made with 27 data points: three points along the system; three crops; three samples per point. The single equations were done with 78 data points each: 27 points per species and three species.

The equations were made via linear regression, and linear, potential, exponential and logarithmic equations were analyzed. The choice was based on the coefficient of determination $\left(\mathrm{R}^{2}\right)$, that is, the type of equation chosen was the one with the highest $\mathrm{R}^{2}$.

\section{RESULTS AND DISCUSSION}

Eighty-one data were obtained per parameter, 9 for each point for each species. The averages of the 9 data collected from DMY and NEC are shown in Table 1. 
Table 1. Average dry matter yield and nutrient extraction capacity for the three species analyzed.

\begin{tabular}{lccccccccc}
\hline & \multicolumn{3}{c}{ T. latifolia } & \multicolumn{3}{c}{ A. philoxeroides } & \multicolumn{3}{c}{ C. dactylon } \\
\hline HRT (d) & $\mathbf{0 . 8}$ & $\mathbf{2 . 4}$ & $\mathbf{4 . 0}$ & $\mathbf{0 . 8}$ & $\mathbf{2 . 4}$ & $\mathbf{4 . 0}$ & $\mathbf{0 . 8}$ & $\mathbf{2 . 4}$ & $\mathbf{4 . 0}$ \\
\hline DMY $\left(\mathbf{t ~ h a}^{-1}\right)$ & 22.3 & 21.1 & 20.2 & 27.9 & 25.4 & 23.1 & 26.8 & 27.5 & 27.2 \\
NEC-TN $\left(\mathbf{k g ~ h a}^{-1}\right)$ & 500.8 & 539.1 & 499.2 & 1252.7 & 946.0 & 910.7 & 752.5 & 643.2 & 603.9 \\
NEC-TP $\left(\mathbf{k g ~ h a}^{-1}\right)$ & 85.9 & 84.8 & 82.5 & 142.7 & 136.9 & 117.9 & 124.3 & 101.6 & 88.4 \\
NEC-TK $\left(\mathbf{k g ~ h a}^{-1}\right)$ & 628.8 & 594.9 & 645.5 & 1263.9 & 1162.0 & 1008.5 & 659.6 & 559.6 & 510.8 \\
\hline
\end{tabular}

DMY: Dry matter yield; NEC-TN: nitrogen extraction capacity; NEC-TP: phosphorus extraction capacity; NEC-TK: Potassium extraction capacity.

In this data manipulation step, 18 equations were obtained (Figures 3 and 4) which represent the behavior of the DM productivity and total nitrogen, ammonium, nitrate, phosphorus and potassium extraction from the aerial part of plants along the length of systems, that is, in relation to HRT. Each part of the figure shows the behavior of these variables in each harvest and the curve of the average values in the harvested material.

The mathematical model that presented the highest accuracy for the $\mathrm{N}$ and $\mathrm{P}$ extraction data by the aerial parts of the plant and for the dry matter yield was the decreasing potential. For the extraction of $\mathrm{K}$, the model with the highest adjustment was the linear decreasing.

It was observed that there was a decrease in DMY and NEC with the increase in HRT, other than the $\mathrm{N}$ and $\mathrm{K}$ extraction capacity, by T. latifolia.

The ability of plants to extract nutrients from wastewater under treatment and their productivity is directly associated with the availability of nutrients in mineral form. This availability, in turn, depends on the Organic Load Rate (OLR) applied in the CW,

As in this experiment there was a decrease in productivity and nutrient extraction capacity with increase in OLR, nutrient availability in mineral form decreased with HRT in CWs. The extraction capacity of $\mathrm{N}$ in the present research was, on average, $738.7 \mathrm{~kg} \mathrm{ha}^{-1}$, in an average culture period of 180 days, when submitted to OLR of $155 \mathrm{~kg} \mathrm{ha}^{-1} \mathrm{~d}^{-1}$ of BOD. Queiroz et al. (2004) obtained $552 \mathrm{~kg} \mathrm{ha}^{-1} \mathrm{~N}$ extraction in 120 days of continuous SWW application.

Matos et al. (2010), when evaluating the extraction capacity of two plant species (Pennisetum purpureum schum and Cynodon spp.), when grown on HSSF-CWs used in the treatment of dairy wastewater, observed a tendency of increase in TN, TP and TK extraction with the increase in OLR applied. These authors obtained, in a period of 61 days of cultivation of the first species and 45 days of the second, in HSSF-CW submitted to OLR of $570 \mathrm{~kg} \mathrm{ha}^{-1} \mathrm{~d}^{-1}$ of BOD, obtained an estimated maximum value of 205.7 and Of $356 \mathrm{~kg} \mathrm{ha}^{-1}$, in the extraction of N-total, 30.2 and $37.8 \mathrm{~kg} \mathrm{ha}^{-1}$, in the extraction of P-total and 8.6 and $14.9 \mathrm{t} \mathrm{ha}^{-1}$ in the DMY.

In addition to the cultivation period and applied organic load, it is understood that the type of effluent used and the climatic conditions are decisive factors in the comparison of DMY and NEC of different plant species. It is assumed that the mathematical models proposed and adjusted in this work apply only to the treatment of SWW in HSSF-CW.

Thus, the differences in concentration between the three harvests may also be due to the climatic conditions of each crop. The first occurred in the autumn, the second in the winter, and the third in the spring. It is observed that the species Typha latifolia and Cynodon dactylon presented higher DMY and NEC in the first harvest (autumn) and Alternanthera philoxeroides in the third harvest (spring).

It must be emphasized that the equation presented in each part, and its coefficient of determination, refer to the mathematical adjustment of the average curve. In addition, it was considered that coefficient of determination $\left(\mathrm{R}^{2}\right)$ greater than 0.7 represent a good correlation between the variables. 
It is noted that only five of the 18 equations obtained showed $\mathrm{R}^{2}$ lower than 0.7 , having been obtained basically in CW 1 (cultivated with $T$. latifolia), which can be associated with the effect of the greater decomposition of masses of stem and root/rhizomes of plants, increasing the amount of soluble nutrients in the medium.

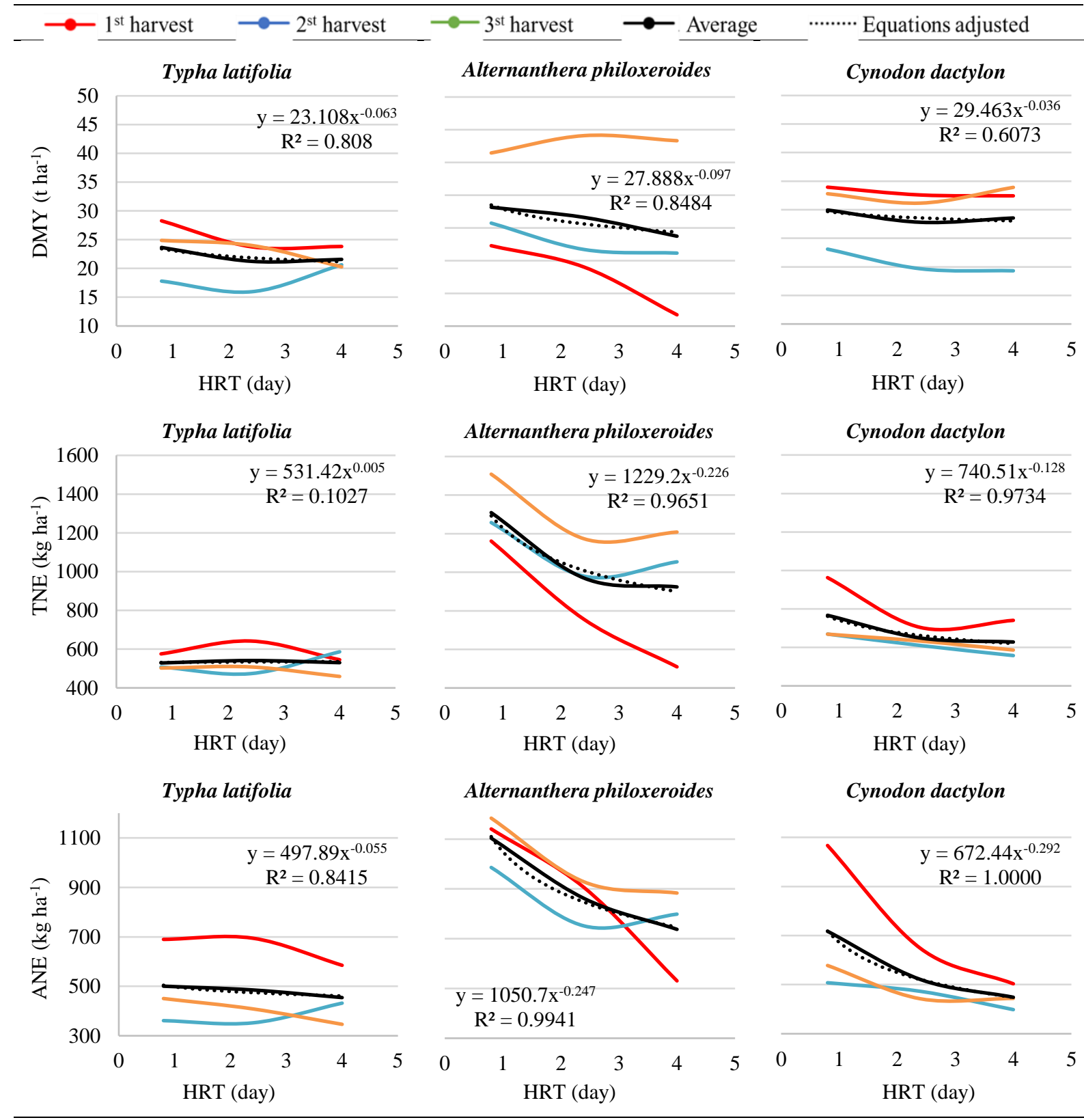

DMY: dry matter yield; TNE: Total nitrogen extraction; ANE: Ammonium nitrogen extraction; HRT: hydraulic retention time.

Figure 3. Equations for dry matter yield and extraction by plant aerial parts of total nitrogen and ammonium, respectively, in relation to hydraulic retention time in the HSSF-CWs. 

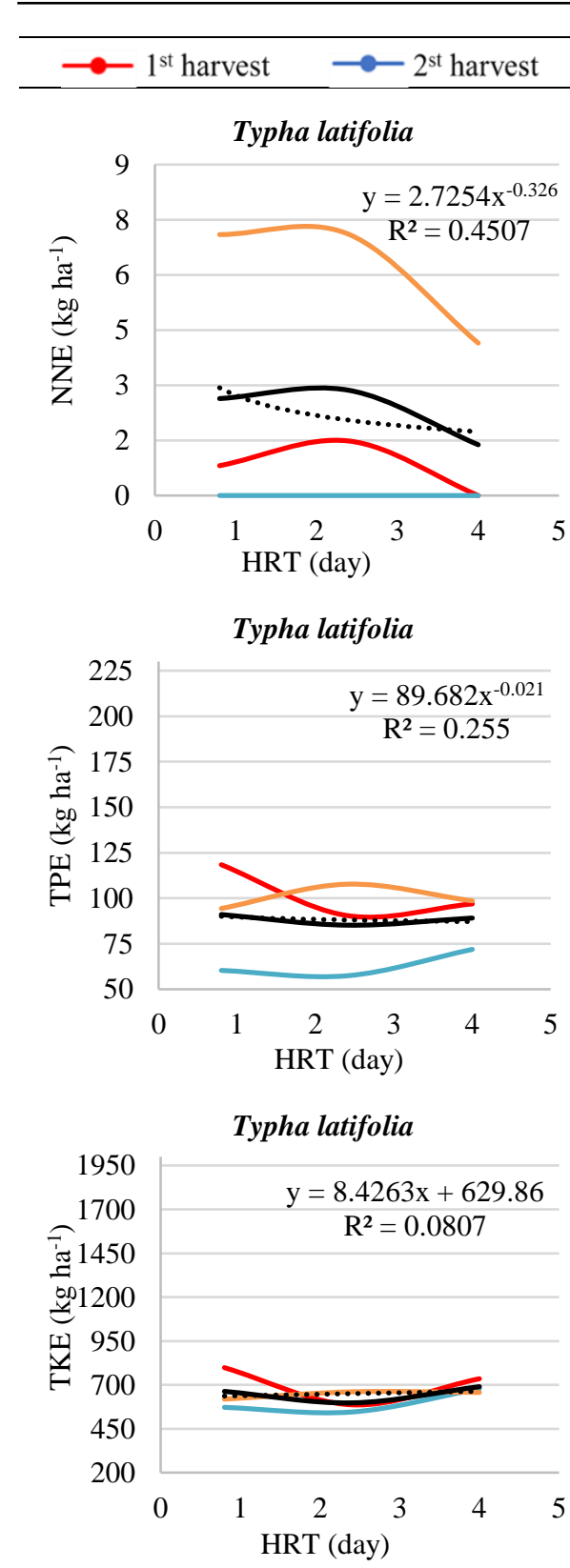

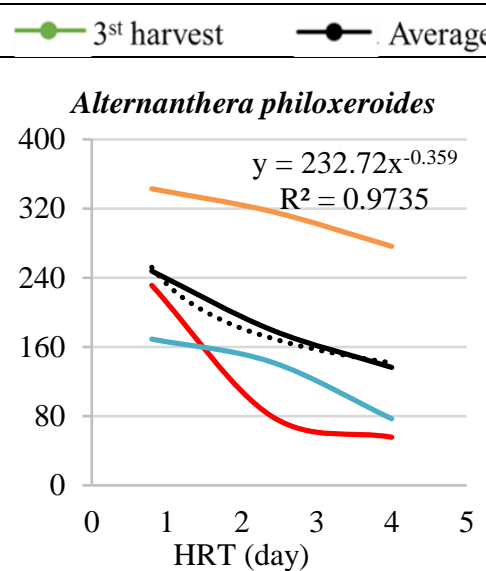

Alternanthera philoxeroides

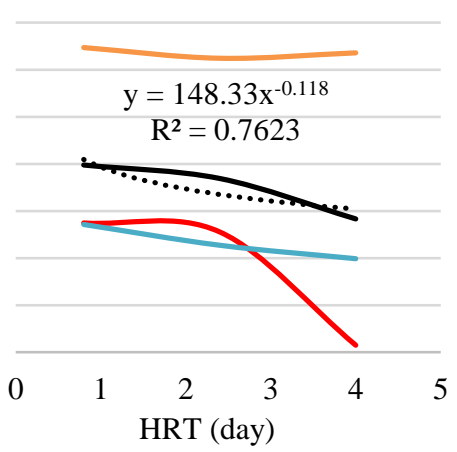

Alternanthera philoxeroides

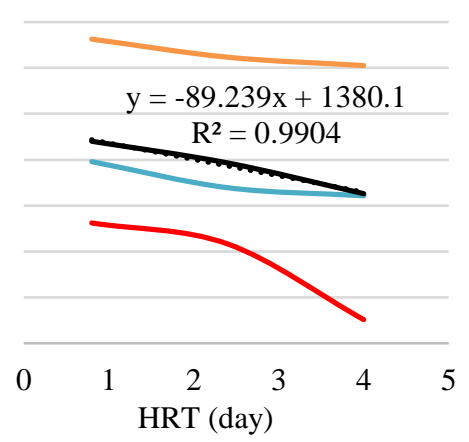

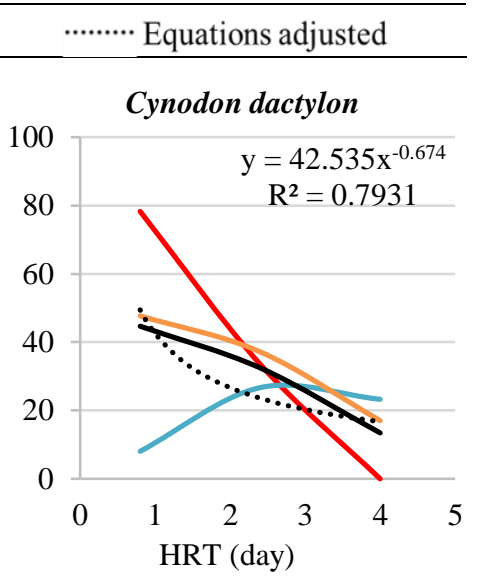

Cynodon dactylon

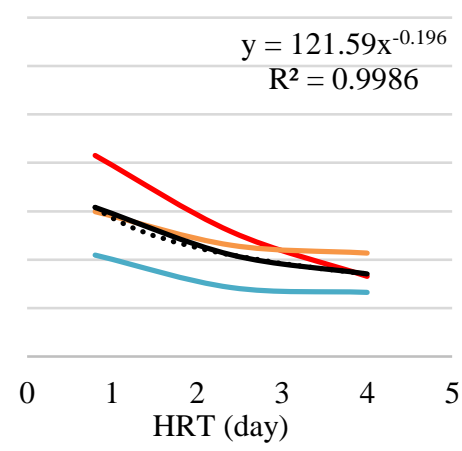

Cynodon dactylon

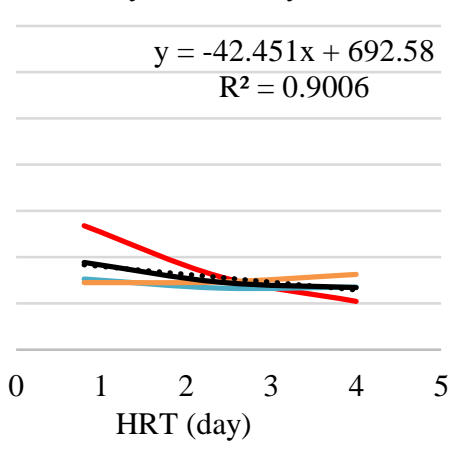

NNE: Nitrate nitrogen extraction; TPE: Total nitrogen extraction; TKE: Total potassium extraction; HRT: hydraulic retention time.

Figure 4. Equations for extraction by plant aerial parts of nitrate, phosphorus and potassium, respectively, in relation to hydraulic retention time in the HSSF-CWs.

For creating single equations, i.e., that do not depend on the species planted in HSSFs-CW, the curves obtained for each species were clustered, using the method of similarity analysis between curves of Pearson. The Pearson correlation index between curves was low (bellow 0.7) in the analysis of dry mass productivity to the pair A. philoxeroides and $C$. dactylon. In this case, for the creation of a single equation, the averages of productivity from $C$. dactylon, were excluded, once they presented lower adjustment. Adjusted single equations are shown in Figure 5. All of them presented $\mathrm{R}^{2}$ values higher than 0.9 . 


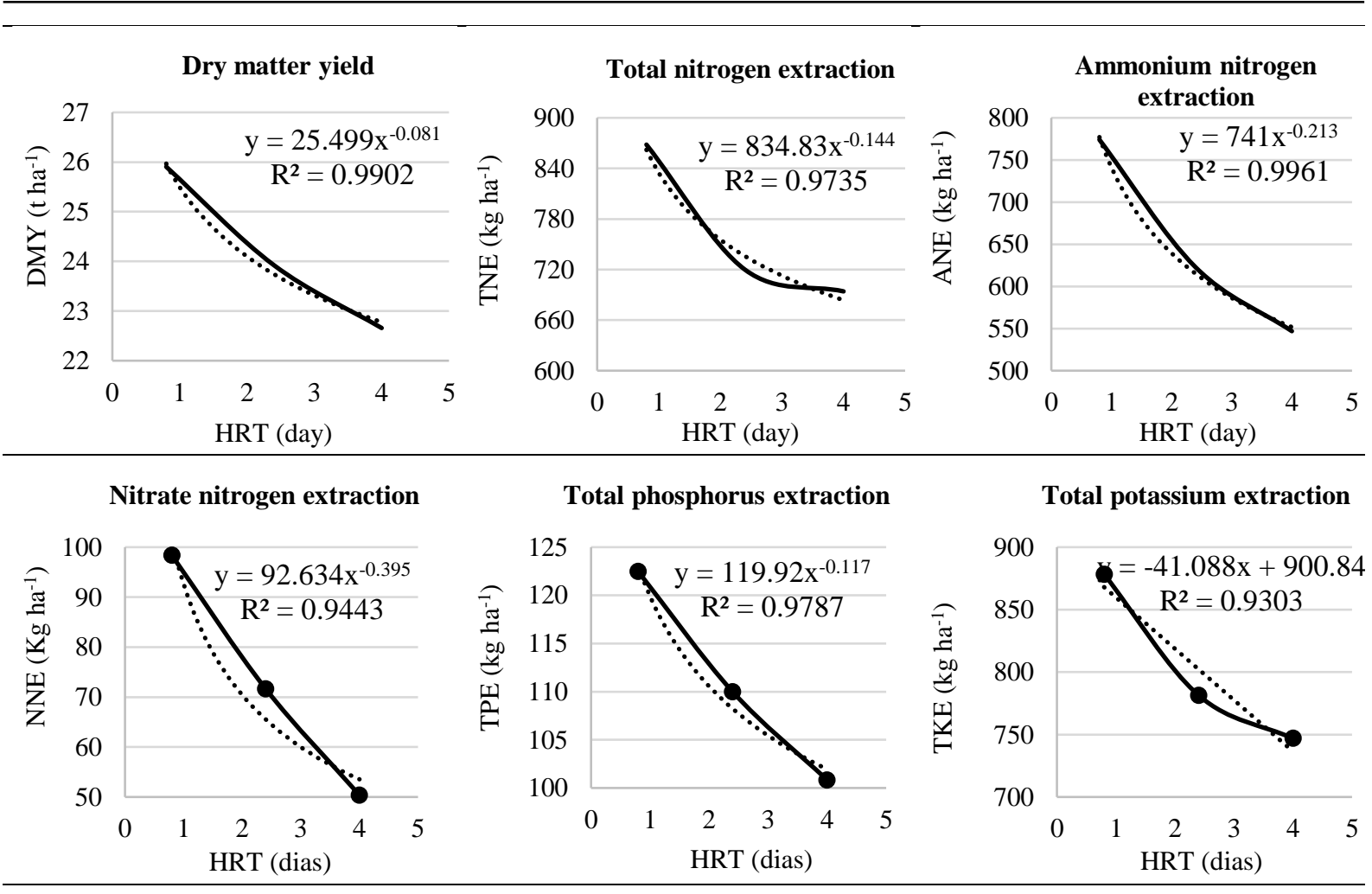

DMY: dry matter yield; TNE: Total nitrogen extraction; ANE: Ammonium nitrogen extraction; NNE: Nitrate nitrogen extraction; TPE: Total nitrogen extraction; TKE: Total potassium extraction; HRT: hydraulic retention time.

Figure 5. Single equation that correlates dry matter yield and extraction by plant aerial parts of total nitrogen, ammonium, nitrate, phosphorus and potassium, respectively, in relation to hydraulic retention time in the HSSF-CWs.

Finally, the developed equations are specific for the organic loading rate (type of treated effluent), the growing days of each species and the climatic conditions. Table 2 shows a summary of the data obtained from DMY and NEC for the three species studied and their environmental conditions. These results highlight the importance of the presence and selection of the plant species to be cultivated in HSSF-CWs, in accordance with the objectives to be achieved in relation to wastewater treatment in these systems.

Table 2. DMY and NEC values for the three species studied.

\begin{tabular}{|c|c|c|c|c|c|c|c|}
\hline $\begin{array}{l}\text { Type of } \\
\text { effluent }\end{array}$ & Flow type & $\begin{array}{c}\text { Days of } \\
\text { cultivation }\end{array}$ & $\begin{array}{c}\text { OLR } \\
\left(\mathrm{kg} \mathrm{ha}^{-1} \mathbf{d}^{-1}\right)\end{array}$ & Species & $\begin{array}{c}\text { DMY } \\
\left(\mathbf{t ~ h a}^{-1}\right)\end{array}$ & $\begin{array}{c}\text { NEC-TN } \\
\left(\mathrm{kg} \mathrm{ha}^{-1}\right)\end{array}$ & $\begin{array}{r}\text { NEC-TP } \\
\left(\mathrm{kg} \mathrm{ha}^{-1}\right)\end{array}$ \\
\hline \multirow{3}{*}{$\begin{array}{l}\text { Swine waste } \\
\text { water }\end{array}$} & \multirow{3}{*}{ Horizontal } & \multirow{3}{*}{180} & \multirow{3}{*}{155} & Typha latifolia & 21.2 & 513.1 & 84.4 \\
\hline & & & & A. philoxeroides & 25.5 & 1036.4 & 132.5 \\
\hline & & & & Cynodon dactylon & 27.2 & 666.6 & 104.8 \\
\hline
\end{tabular}

\section{CONCLUSION}

The mathematical model that best fit the experimental data of dry matter yield and $\mathrm{N}$ and $\mathrm{P}$ extraction by plant aerial parts was the decreasing potential, while linear decreasing fit better for $\mathrm{K}$ extraction.

The relatively low fitting of the curves to the data of dry matter yield for each species can be associated with the wide variation in yields obtained in the different harvests. The cuts were conducted at different times of the year and may reflect the difference in climatic conditions

\section{IPABH}


between the different sampling times - a factor that would have a considerable influence on productivity.

The adjustment curves of nutrient extraction for T. latifolia did not show good correlation, which can be explained by the greater variability in data, possibly resulting from the effect of the greater decomposition of stem and root/rhizomes biomasses, increasing the amount of soluble nutrients in the medium.

The single equations generated to estimate the nutrient extraction by aerial parts of the assessed plant species along the length of HSSF-CW, presented $\mathrm{R}^{2}$ values always higher than 0.9 . The results give an indication that the decrease in plant productivity is possibly due to the lower availability of nutrients $(\mathrm{N}, \mathrm{P}$ and $\mathrm{K})$ in swine wastewater along the length of these systems.

The equations generated in this paper can contribute to plant species selection, the design and operational conditions of wetlands systems, with a better understanding of the influence of plants, maximizing efficiency in the treatment of swine wastewater.

\section{REFERENCES}

ASSOCIAÇÃO BRASILEIRA DOS CRIADORES DE SUÍNOS - ABCS. Mapeamento da suinocultura brasileira. 1. Ed. Brasília, 2016. 376 p. Available: http://www.abcs.org.br/attachments/-01_Mapeamento_COMPLETO_bloq.pdf. Access: 14 Ago. 2017.

FAQUIN, V. Nutrição mineral de plantas. Lavras: UFLA/FAEPE, 2005. 186 p.

KONZEN, E. A. Aproveitamento de dejetos líquidos de suínos para fertirrigação e fertilização em grandes culturas. Sete Lagoas: EMBRAPA, 2003. 11 p.

LAUTENSCHLAGER, S. R. Modelagem do desempenho de Wetlands construídos. 2001 $\mathrm{PhD}$ thesis (Doctorate) - Departamento de Engenharia Hidráulica e Sanitária, Escola Politécnica, Universidade de São Paulo, São Paulo, 2001.

MATOS, A. T.; ABRAHÃO, S. S.; LO MONACO, P. A. V.; SARMENTO, A. P.; MATO, M. P. Capacidade extratora de plantas em sistemas alagados utilizados no tratamento de águas residuárias de laticínios. Revista Brasileira de Engenharia Agrícola e Ambiental, v. 14, n. 12, p. 1311-1317, 2010.

MATOS, A. T.; MATOS, M. P. Disposição de águas residuárias no solo e em sistemas alagados construídos. 1. ed. Viçosa: Editora UFV, 2017. 357 p.

MEYER, D. F.; CHAZARENC, D.; CLAVEAU-MALLET, U.; DITTMER, N.; FORQUET, P.; MOLLE, A. et al. Modelling constructed wetlands: Scopes and aimS - a comparative

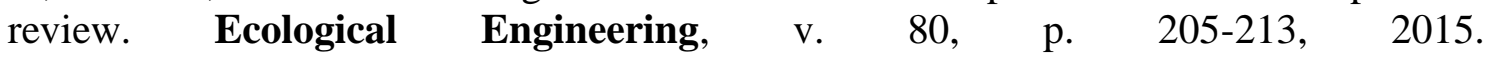
https://doi.org/10.1016/j.ecoleng.2014.10.031

MOHAMMADPOUR, R.; SHAHARUDDIN, S.; CHANG, C. K.; ZAKARIA, N. A.; GHANI, A. A. Spatial pattern analysis for water quality in free surface constructed wetland. Water $\begin{array}{llllllll}\text { Science } & \& & \text { Technology, } & \text { v. } 70, \text { n. } 7, & \text { p. }\end{array}$ http://dx.doi.org/10.2166/wst.2014.343

PERDOMO, C. C.; LIMA, G. J. M. M.; NONES, K. Produção de suínos e meio ambiente. In: SEMINARIO NACIONAL DE DESENVOLVIMENTO DA SUINOCULTURA, 2001, Gramado, RS. Anais... Concórdia: EMBRAPA Suínos e Aves, 2001. p. 8-24. 
QUEIROZ, F. M.; MATOS, A. T.; PEREIRA, O. G.; OLIVEIRA, R. A.; LEMOS, A. L. Características químicas do solo e absorção de nutrientes por gramíneas em rampas de tratamento de águas residuárias da suinocultura. Engenharia na Agricultura, v. 12, n. 2, p. 77-90, 2004.

SAEED, T.; SUN, G. Kinetic modelling of nitrogen and organics removal in vertical and horizontal flow wetlands. Water Research, v. 45, n. 10, p. 3137-3152, 2011. https://doi.org/10.1016/j.watres.2011.03.031

UNITED STATES. Environmental Protection Agency - USEPA. Design manual on constructed wetlands and aquatic plant systems for municipal wastewater treatment. Whashington, 1999.

VON SPERLING, M. Introdução à qualidade das águas e ao tratamento de esgoto. Belo Horizonte: Editora UFMG, 2005. 452 p.

VYMAZAL, J. Plants in constructed, restored and created wetlands. Ecological Engineering, v. 61, p. 501-504, 2013.

WETLAND INTERNATIONAL. The use of constructed wetlands for wastewater treatment. Malaysia Office, 2003. Available in: http://www.wetlands.org/Portals/0/publications/Book/Contructed. Access: 02 Sep. 2015. 